\title{
OPTIMIZED CFRAL COMPOSITE FOR AdVAnCEd Aerospace Applications
}

\author{
TACHE, F.; DOBRE, T. \& TACHE, A. A.
}

Abstract: The research depicted in this paper thoroughly investigates the design, production and testing of a new composite material that combines properties of homogeneous materials with those of carbon fibers, thus resulting a lightweight structure with good mechanical and thermal resistance, while having a price comparable to that of existing products and complying with all applicable environmental requirements. CFRAl properties and manufacturing technology are optimized through theory and experiments, thus engaging the developing process of the new composite in an iterative cycle with feedback on both ways, from theory to experiment and vice versa. Though a daring challenge, Carbon Fibers Reinforced Aluminum is a new type of composite material being developed by the Chemical Engineering Department in cooperation with the Faculty of Aerospace Engineering at University 'POLITEHNICA' of Bucharest, Romania. The new composite has unique and promising properties, with foreseeable excellent results in applications requiring a reliable, yet light, reinforcement material that can also withstand powerful thermal shocks. Current study represents a continuation of the work started within the last four years at UPB and is an integral part of the first author's PhD study.

Key words: carbon fibers, explosion, bullet-proof, hybrid composite
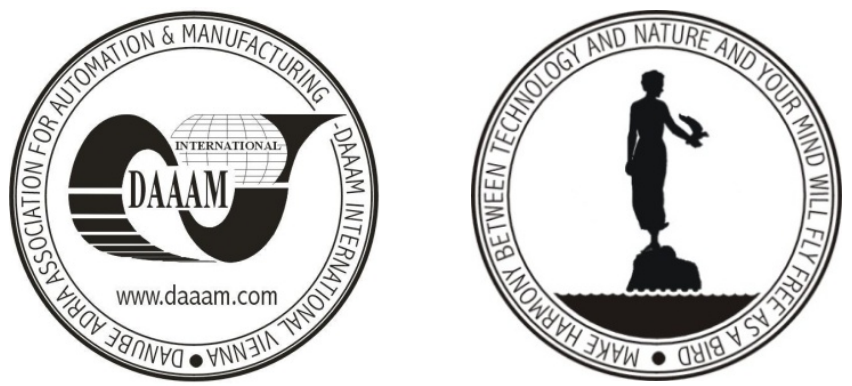

Authors' data: MSc. Dipl.-Ing. PhD student Tache, F[lorin]; Univ. Prof. Dipl.-Ing. Dr. Sc. Dobre, T[anase]; MSc. Dipl.-Ing. Tache, A[lina] A[lexandra], University „POLITEHNICA“ of Bucharest, Faculty of Applied Chemistry and Materials Science, Mass Transfer Laboratory, 1-7 Gh. Polizu str., sector 1, 011061, Bucharest, Romania; flotasoft@yahoo.com, tdobre@mt.pub.ro, ada_chirilus@yahoo.com

This Publication has to be referred as: Tache, F[lorin]; Dobre, T[anase] \& Tache, A[lina] A[lexandra] (2009). Optimized CFRAl Composite for Advanced Aerospace Applications, Chapter 53 in DAAAM International Scientific Book 2009, pp. 531548, B. Katalinic (Ed.), Published by DAAAM International, ISBN 978-3-90150969-8, ISSN 1726-9687, Vienna, Austria

DOI: $10.2507 /$ daaam.scibook.2009.53 